Etnográfica

Revista do Centro em Rede de Investigação em

Antropologia

vol. 20 (1) | 2016

Vol. 20 (1)

\title{
"Legales pero ilegítimos": sentidos sobre la inscripción de la filiación y los documentos personales para quienes buscan sus orígenes en Argentina
}

"Legal but illegitimate": senses on registration of filiation and personal documents for those seeking their origins in Argentina

\section{Soledad Gesteira}

\section{OpenEdition \\ Journals}

Edición electrónica

URL: https://journals.openedition.org/etnografica/4159

DOI: 10.4000/etnografica.4159

ISSN: 2182-2891

Editor

Centro em Rede de Investigação em Antropologia

Edición impresa

Fecha de publicación: 1 febrero 2016

Paginación: 5-31

ISSN: 0873-6561

Referencia electrónica

Soledad Gesteira, «"Legales pero ilegítimos": sentidos sobre la inscripción de la filiación y los

documentos personales para quienes buscan sus orígenes en Argentina», Etnográfica [En línea], vol. 20 (1) | 2016, Publicado el 03 marzo 2016, consultado el 09 febrero 2022. URL: http://

journals.openedition.org/etnografica/4159; DOI: https://doi.org/10.4000/etnografica.4159

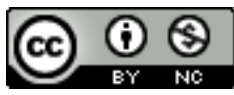

Etnográfica is licensed under a Creative Commons Attribution-NonCommercial 4.0 International License. 


\section{"Legales pero ilegítimos": sentidos sobre la inscripción de la filiación y los documentos personales para quienes buscan sus orígenes en Argentina}

\section{Soledad Gesteira}

A partir del trabajo de campo en una asociación argentina de personas que buscan sus orígenes y de entrevistas en profundidad a activistas de este campo, en este artículo indago sobre las formas que asume la inscripción de la filiación si hubo una adopción o cuando fueron inscriptos falsamente como si fueran hijos biológicos. Asimismo, analizo los sentidos otorgados por estas personas a sus documentos personales que caracterizan como "legales pero ilegítimos" dado que sus datos no son "verdaderos". Por último, examino las estrategias que despliegan para volver legítimos sus documentos, es decir, para rectificar y/o modificar su filiación. Las características de sus documentos revelan la complejidad de sus búsquedas en donde la filiación biológica queda en suspenso a la espera de conocer la "verdad". Estos casos echan luz sobre el carácter socialmente construido de la filiación y sobre las diversas recombinaciones que pueden asumir las dimensiones biológica y social que la componen.

PALABRAS CLAVE: filiación, documentos, adopción, falsa inscripción, orígenes.

"Legal but illegitimate": senses on registration of filiation and personal documents for those seeking their origins in Argentina - Based on ethnographic fieldwork performed in an Argentinean association dedicated to persons seeking their origins and in-depth interviews to activists in this field, in this article I inquire the various ways the registration of paternity is assumed if there is an adoption or when they are falsely enrolled as biological children. I also analyze the meaning given by these people to their personal documents characterized as "legal but illegitimate" because there is no "real" data. Finally, I examine the strategies carried out by these activists to legitimate those documents by modifying and/ or correcting their filiation record. The characteristics of these documents reveal the complexity behind this process in which biological parentage remains on hold waiting for "the truth" to be uncovered. These cases demonstrate the nature of the social construction around filiation and the multiple combinations that biological and social dimensions can assume.

KEYWORDS: filiation, documents, adoption, false registration, origins.

GESTEIRA, Soledad (soledadgesteira@gmail.com) - UBA-CONICET, Argentina. 


\section{INTRODUCCIÓN}

El surgimiento de movimientos de activistas que buscan sus orígenes puede ubicarse en los Estados Unidos entre las décadas de los 60 y $70^{1}$ (Amorós, Fuertes y Paula 1996; Fonseca 2009) en la lucha en favor de la apertura de los archivos en los casos de adopciones cerradas. ${ }^{2}$ Asimismo, la aparición de este tipo de demandas se vincula a nivel global con los procesos que ha desencadenado la adopción internacional (Marre 2004; Yngvesson 2007; Howell 2004). Tanto en Suecia como en otros países con altos índices de adopción internacional, existen redes informales de apoyo y organizaciones formales conformadas por adoptados (Yngvesson 2007). Asimismo, pueden identificarse asociaciones de personas que quieren conocer sus orígenes en Italia (Astro Nascente Adozione e Origini Biologiche), Francia (Association pour le droit aux origines des enfants nés sous X), Grecia (SEASYP Greek Reunion Registry), y España, en donde las asociaciones se vinculan al robo de niños ocurrido desde la década del 30 con el franquismo hasta los años 90 en clínicas privadas y hospitales públicos (Duva y Junquera 2011; Marre 2014; González de Tena 2014). La amplitud del movimiento político de búsqueda de los orígenes se evidencia en las diversas situaciones que motivan a las personas a "conocer sus orígenes", a saber: las adopciones cerradas, la adopción internacional, los desplazamientos forzados, el robo y la apropiación de niños. ${ }^{3}$ A su vez, en los últimos años comenzaron a surgir asociaciones de hijos de donantes anónimos que quieren conocer sus orígenes (Théry 2009). ${ }^{4}$

En Argentina, la cuestión de los orígenes y la identidad tiene una indiscutible relación con el trabajo realizado por la Asociación Abuelas de Plaza de Mayo en la búsqueda de sus nietos apropiados durante la última dictadura militar (1976-1982). ${ }^{5}$ Ciertamente a partir de su labor, en nuestro país muchas

1 Una de las asociaciones pionera fue ALMA (Adoptees Liberty Movement Association), fundada en 1971 por la activista Florence Fischer quien describió su propia búsqueda de origen en The Search for Anna Fischer (Boston, Arthur Fields Books, 1973). Asimismo, más tarde han surgido otras asociaciones similares, entre las cuales se destaca Bastard Nation, fundada en 1996.

2 Son confidenciales, es decir que no hay contacto entre los padres adoptivos y los padres biológicos luego de la adopción, y en consecuencia el adoptado no puede acceder a la información sobre su origen biológico.

3 En este punto cabe señalar a la asociación alemana Lebensspuren (Huellas de Vida) creada en 2005 por personas que fueron robadas a partir del plan Lebensborn implementado durante el nazismo, y también a la asociación australiana GMAR (Grandmothers Against Removals) creada en 2014 por personas víctimas de lo que se conoce como "generaciones robadas", niños indígenas que entre 1890 y 1970 fueron forzosamente sacados de sus hogares y colocados en familias blancas o en instituciones a fines de "asimilarse".

4 Por ejemplo, la asociación belga Donorkinderen.

5 En este período fueron secuestrados alrededor de 500 niños y niñas, hijos de militantes que fueron detenidos y desaparecidos. En 1977 nace la asociación Abuelas de Plaza de Mayo con el objetivo de localizar a sus nietos y restituirlos a sus familias de origen. 
personas, que sabían que eran adoptadas o que sospechaban que podían serlo, comenzaron a preguntarse sobre sus orígenes y su identidad, y posteriormente se organizaron y formaron sus propias asociaciones en donde luchan por el cumplimiento del derecho a conocer sus orígenes. ${ }^{6}$ Una de esas asociaciones es Raíz Natal "Por el Derecho a la Identidad Biológica", 7 surgida en 2003 y formada por personas, de entre 30 y 80 años, que se nuclearon para encontrar sus orígenes y orientar a otras personas en la búsqueda de información relativa a las circunstancias de su nacimiento y a su familia biológica. ${ }^{8}$ En su página web sostienen: "por querer conocer nuestra historia nos encontramos; para descubrir nuestras raíces nos unimos, y porque estamos juntos en busca de la verdad, formamos Raíz Natal". ${ }^{9}$ Si bien comúnmente se suele decir que estas personas son adoptadas, muchas de ellas no fueron adoptadas mediante un trámite legal, sino que han sido anotadas en el Registro Civil como hijos biológicos por sus padres de crianza, es decir que fueron inscriptos falsamente, una acción que formalmente constituye un delito. ${ }^{10}$ Es por ello que en la Asociación afirman que los documentos personales que resultan de sus falsas inscripciones son "legales pero ilegítimos". ${ }^{11} \mathrm{La}$ aparente contradicción que encierra dicha expresión, la recurrencia con la que se presentaba en el trabajo de campo y la importancia que era atribuida a los documentos personales en estas búsquedas, me llevaron a interrogarme sobre las características que éstos asumen en las falsas inscripciones y también cómo son concebidos estos "papeles" por estas personas.

Este artículo se basa en el trabajo de campo etnográfico que llevé adelante entre 2010 y 2014 en la Asociación, en las observaciones que realicé en el debate de un proyecto de ley sobre el derecho a la identidad de origen y biológica - que tuvo lugar durante 2013 y 2014 en la Ciudad de Buenos Aires -, y en las entrevistas en profundidad realizadas a diferentes activistas de este

6 Sobre las implicancias políticas de la relación entre el discurso y la práctica de Abuelas de Plaza de Mayo con la construcción de las demandas de las nuevas asociaciones de personas que buscan sus orígenes se puede consultar el texto "Más allá de la apropiación criminal de niños: el surgimiento de organizaciones de personas 'adoptadas' que buscan su 'identidad biológica' en Argentina” (Gesteira 2014). Allí se analiza cómo estas nuevas asociaciones retoman el discurso entorno al "derecho a la identidad" construido por Abuelas de Plaza de Mayo, resinificándolo e incorporando nuevos términos a la identidad, tales como biológica y de origen.

7 En adelante me referiré a ella como la Asociación.

8 Todas las actividades que realiza la Asociación son solventadas por sus integrantes ya que no reciben ningún tipo de financiamiento y/o subsidio.

9 En < http://www.raiznatal.com.ar > (ultima consulta en enero 2016).

10 Los artículos 146, 138, 139 y 243 del Código Penal condenan el robo de niños bajo las figuras de sustracción, retención y ocultamiento de un niño menor de 10 años; suposición y sustitución de estado civil y falsedad ideológica de instrumentos públicos. Las penas oscilan entre 1 y 15 años de prisión y prescriben a los 12 años.

11 Según las estimaciones de la Asociación, el 80 por ciento de quienes inician una búsqueda de origen fueron inscriptos falsamente y un 20 por ciento han sido adoptados. 
campo. Puntualmente en este trabajo analizo los sentidos que son otorgados a los documentos personales por quienes buscan conocer sus orígenes, así como por sus padres de crianza y por el Estado en la figura de sus funcionarios. Por último, examino las estrategias que llevan adelante para volver legítimos sus documentos, es decir, para modificar, rectificar y/o corregir sus filiaciones.

Los diversos elementos analizados a lo largo del artículo resultan miradores privilegiados para observar cómo el parentesco en nuestras sociedades se presenta constituido por diferentes dimensiones - biológica, social, jurídico-burocrática (Martínez 2010) - y los modos en que tales dimensiones, que se encuentran imbricadas y se constituyen mutuamente, pueden entrar en conflicto, contradicción y ambigüedad. Al mismo tiempo, revelan que la filiación, lejos de ser algo dado de una vez y para siempre, puede ser cuestionada, rectificada y rechazada, lo que expone su carácter socialmente construido.

\section{FALSAS INSCRIPCIONES Y ADOPCIONES}

La antropología ha demostrado que el hecho biológico del nacimiento es reinterpretado y retraducido por cada grupo social atendiendo a sus propias lógicas y es acompañado de una serie de rituales que, de una manera u otra, formalizan esa manera de introducir en un grupo social a los miembros de las nuevas generaciones (Zonabend 1986; Cadoret 2004, 2009; Godelier 2014). Ahora bien, ¿cuáles son esos rituales en nuestras sociedades modernas? ¿Quién es el encargado de formalizar el ingreso de un nuevo miembro a un grupo social determinado? En nuestra sociedad, cuando nace un niño la primera obligación legal para sus padres es la inscripción de su nacimiento. Como señala Josefina Martínez, "la regla dice que se nace en el seno de una familia formada por un padre y una madre, y toda la burocracia estatal está organizada para registrar estos sucesos y darles una forma legal: la filiación" (2004: 405). En Argentina, cuando un niño nace, tal como lo indican los procedimientos burocráticos de rutina, debe ser inscripto por sus padres como hijo en el Registro del Estado Civil y Capacidad de las Personas. La forma en que los padres realizan la inscripción en el Registro Civil difiere según se trate de una filiación matrimonial o extramatrimonial.

La ley argentina presume que los niños nacidos luego de la celebración del matrimonio son hijos del marido, lo que habilita a cualquiera de los padres a realizar la inscripción en el Registro Civil con la libreta de matrimonio.

En el caso de que los padres no estén casados, ambos tienen que acudir al Registro Civil para realizar la inscripción, y en ese acto el padre "reconoce" al hijo. En el caso de una paternidad extramatrimonial, si el padre no va al registro Civil a reconocer al niño puede ser obligado a ello mediante un juicio de filiación. 
En los casos de adopción, la inscripción de la filiación en el Registro Civil se realiza luego del dictado de la sentencia del juicio correspondiente.

De la inscripción en el Registro Civil resulta la partida de nacimiento, el documento que certifica dónde nacimos, hijos de quiénes somos, el domicilio del nacimiento, la firma del médico que intervino, entre otros datos. Actualmente, en Argentina, el plazo legal para inscribir a un niño después de su nacimiento es de 40 días y se debe presentar un certificado médico que lo acredite firmado por el médico que asistió el parto y un certificado de vacunación.

Estas normativas respecto de quiénes pueden y/o deben realizar la inscripción del niño, los plazos de la inscripción y los documentos a presentar fueron modificándose a través del tiempo, dependiendo de los cambios en las normativas para la inscripción de nacimientos.

La filiación, sostiene Martínez, "no es algo que grupos humanos a lo largo de la historia hayan dejado librado al azar [...], por el contrario, por todas partes y en todas épocas los grupos sociales han formulado principios, reglas, normas y procedimientos para establecer y registrar la filiación de los nuevos integrantes" (2010: 285). Por ello la filiación es el resultado de un diálogo no exento de conflictos entre las dimensiones biológica y jurídica (Martínez 2010). Al nacimiento biológico se une el nacimiento jurídico, por el que se realiza el reconocimiento como hijo. Es con la inscripción en el Registro Civil que se lleva a cabo el "nacimiento jurídico" (Martínez 2004). Cabe entonces comprender a la filiación como un proceso de construcción social, es decir un artefacto jurídico e histórico resultado de las normas sociales que son impuestas a la reproducción biológica (Godelier 1993). Si bien, la antropología ha ofrecido sobradas evidencias (Schneider 1984; Segalen 1992; Strathern 1992, entre otros) del carácter artefactual, construido e histórico del parentesco, la filiación, la familia y el género, aún en nuestros días se continúa dotando a los hechos del parentesco y la familia de interpretaciones biológico-naturales, ello así debido a la singular impronta heterobiologicista del modelo de parentesco euroamericano (Schneider 1984; Carsten 2000a). ${ }^{12}$

Ahora bien, para las personas que han sido adoptadas cuando eran pequeñas y actualmente se nuclean en asociaciones que propician la búsqueda de sus orígenes biológicos, la inscripción de la filiación comporta un tema central de interés. ${ }^{13}$ Para algunas de las personas que dudan sobre sus orígenes, esto es,

12 Por cuestiones de extensión, entre otras, no forma parte de los objetivos de este artículo analizar las construcciones y configuraciones de sentidos sobre el parentesco y la familia que sostienen y ponen en juego las personas que buscan sus orígenes de nacimiento. Para un análisis sobre estas cuestiones, consultar el texto: "Buscar el 'origen biológico': parentesco y familia en organizaciones de personas 'adoptadas'” (Gesteira 2013).

13 Una amplia literatura internacional ha analizado las prácticas de adopción y circulación de niños tanto en sociedades lejanas como en las sociedades occidentales (Lallemand 1993; Modell 1994; Fonseca 1998; Cadoret 2004; Villalta 2006; Vianna 2010). Estos - y otros - análisis desde [continua] 
que sospechan que quienes las criaron no son sus padres biológicos, o incluso para aquellas personas que "desde siempre" supieron que habían sido "adoptadas", ${ }^{14}$ la partida de nacimiento y los datos consignados en ella se vuelven elementos centrales a la hora de emprender lo que denominan como la búsqueda de su "identidad biológica" o "verdadera identidad de origen". Ello es así porque en la gran mayoría de los casos estas personas han sido "adoptadas" mediante una falsa inscripción. ${ }^{15}$

Se denomina "falsas inscripciones" a los casos en los que se anota como hijo biológico a un niño que no lo es, lo que supone un delito. ${ }^{16}$ Por el contrario, en la adopción media una tramitación legal para incorporar a un niño a una familia. Falsificar una partida de nacimiento requiere no solo de la voluntad de quienes figurarán como padres de ese niño o niña, sino de un conjunto de personas (funcionarios, jueces, médicos). De esta manera, cada una de estas personas se convierte en un engranaje fundamental a los fines de fraguar esa filiación. La connivencia de médicos, parteras y funcionarios del Poder Judicial en la práctica de inscribir como propio a un hijo ajeno, así como la existencia de libros de partos paralelos, entre otras irregularidades, tiene larga data en nuestro país (Villalta 2006; Regueiro 2010). En efecto, las reflexiones de Carla Villalta (2006) advierten sobre la significativa tolerancia social, jurídica y legislativa hacia este tipo de inscripciones en la historia de nuestro país. En referencia a los años 60 y 70, la autora sostiene que la ley de adopción de $1971,{ }^{17}$ que fue la que incorporó la adopción plena al ordenamiento legal, contaba entre sus pretensiones la de acabar con las falsas inscripciones; sin

[continuación] la antropología revelan que la categoría circulación de niños visibiliza una diversidad de prácticas relativas a la crianza, cuidado y transferencia de los niños, y justamente allí radica su riqueza. Por otro lado, al concepto de adopción - que también da cuenta de una multiplicidad de prácticas sociales y arreglos diversos - cabe comprenderlo como categoría nativa, en la medida en que asume sentidos específicos dependiendo del contexto de enunciación. Esta apreciación resulta significativa para el caso argentino ya que el término, además de referir a la figura jurídica, resulta útil para quienes buscan sus orígenes para dar cuenta de su status de hijo no biológico.

14 Utilizo las comillas aludiendo salvedad, ya que estas personas no han sido adoptadas mediante un trámite legal, sino que han sido inscriptos falsamente como si fueran hijos biológicos - como ya señalé muchas veces ellos se refieren a su condición diciendo que son "adoptados entre comillas". Lo cierto es que para ellos - y también para mí - resulta una forma sencilla de comunicar que no existe relación biológica con quienes los criaron.

15 Los activistas de este campo utilizan varios términos para dar cuenta de su situación filiatoria (inscriptos falsamente); algunos de ellos son: apropiados, inscriptos como hijos biológicos por los padres de crianza, sustituidos, o - tal como señalé - adoptados entre comillas. Vale señalar que algunos activistas - por ejemplo los integrantes de la Asociación - consideran que utilizar el término apropiación confunde el objetivo de su demanda porque se relaciona con la búsqueda de niños apropiados durante la última dictadura militar.

16 Ver información referida en la nota al pie 10.

17 Ley 19.134, sancionada en julio de 1971 durante la presidencia de facto de Alejandro Agustín Lanusse. Esta derogó a la anterior ley de adopción (13.252) - la primera de nuestro país - sancionada en septiembre de 1948 durante el primer gobierno peronista. 
embargo, éstas lejos estaban de ser valoradas negativamente. Pese a constituir delitos las inscripciones falsas, tenían legitimidad puesto que formaban "parte del universo de lo socialmente admitido y se las consideraba un ejemplo de las buenas intenciones y la generosidad de los adoptantes" (Villalta 2006: 256).

Durante mi trabajo de campo en la Asociación pude observar que los documentos son preservados con gran cuidado, puesto que ellos contienen información del nacimiento jurídico, pero además pueden potencialmente decir algo también del nacimiento biológico (el lugar del nacimiento, el nombre de una partera, entre otros datos). De este modo, estas personas buscan conocer, descubrir el cómo y el por qué de ambos nacimientos, el biológico y el jurídico.

Ahora bien, en el transcurso de mi investigación, en repetidas ocasiones, he escuchado expresiones tales como: "no es lo mismo ser adoptado a que te hayan anotado como hijo propio", "inscribir falsamente a un hijo no es adoptarlo", "la gente no entiende, piensa que todos somos adoptados, pero cuando no hay un trámite legal ino sos adoptado!, somos adoptados entre comillas". Este tipo de expresiones condensan, en parte, uno de los objetivos centrales que tienen los activistas que buscan conocer sus orígenes: señalar la diferencia entre la adopción legal y la falsa inscripción, en tanto práctica ilegal y delictiva. ${ }^{18}$ Ello así porque las posibilidades de encontrar a los padres biológicos difieren sustancialmente si hay una adopción legal o si hay una falsa inscripción. Estas dos modalidades de inscripción incidirán en las características que tome la búsqueda, ya que si en la adopción existe un expediente judicial, donde queda registrada toda la información relativa a dicho proceso, ${ }^{19}$ en la inscripción falsa ni siquiera existen esos rastros burocráticos que, al menos, posibilitan iniciar la búsqueda. Cuando una persona es inscripta falsamente, en su partida de nacimiento figuran como sus padres (biológicos) quiénes son sus padres de crianza, y esa partida certifica una paternidad y maternidad biológicas que son falsas. No existe otro documento a través del que se pueda acceder a información sobre los padres biológicos. De tal manera, si tenemos en cuenta, como Roberto DaMatta advierte para Brasil, que la partida de nacimiento es el documento "más importante" ya que es "la generadora de

18 En este objetivo se puede observar cómo estas nuevas asociaciones dialogan, retoman y resignifican argumentos construidos por Abuelas de Plaza de Mayo. Así, la distinción entre la falsa inscripción y la adopción (que se relaciona con la necesidad de estos activistas de marcar la frontera entre lo que es legal y lo que no lo es) se vincula con una premisa que fue nodal para el activismo de Abuelas de Plaza de Mayo: la de marcar la diferencia entre la adopción - como práctica legal - y la apropiación - como práctica ilegal.

19 En general, en los expedientes de adopción se encuentra información sobre la familia - usualmente sobre la madre - del niño que fue dado en adopción, ya sea porque se la ha citado para que preste su consentimiento o bien porque consta en los informes institucionales (de hogares, hospitales, organismos administrativos) y socio-ambientales que frecuentemente se realizan antes de encaminar a un niño a la adopción. No obstante, la cantidad de información consignada varía ampliamente. 
otros documentos, siendo el punto de partida de la vida cívica de cualquier brasileño" (2002: 58), es posible comprender la centralidad que asume una partida de nacimiento falsa; sobre esa base todos los demás documentos lo serán.

Cuando hay una adopción se mantiene el número del documento nacional de identidad (DNI) otorgado al nacer y se confecciona una nueva partida de nacimiento donde consta la adopción, pero se conserva la partida de nacimiento original. Los adoptantes pueden cambiar el nombre del niño o niña, pero se conserva el DNI. De este modo, si el expediente de adopción se incendió o se extravió, con ese DNI las personas adoptadas pueden buscar su partida de nacimiento original. Tal como Sofía, integrante de la Asociación, me manifestó en una entrevista informal:

"Yo tenía todo [expediente judicial] al alcance de la mano porque fui adoptada, pero no podía avanzar, necesitaba tomar la decisión, por eso fui a la Asociación, ahí encontré el apoyo y la contención necesaria para poder hacerlo" [entrevista informal con Sofía, 10 de septiembre de 2011].

El caso de Sofía, al igual que algunos otros de personas adoptadas, forma parte de un pequeño porcentaje de las búsquedas de la Asociación. La expresión "tenerlo todo" pone de manifiesto la centralidad que adquiere el expediente judicial de adopción en estas búsquedas. Sofía se da cuenta que "tiene todo" (el expediente) para avanzar en su búsqueda una vez que llega a la Asociación y advierte lo "valioso" que era lo que ella tenía, porque no sólo le permite emprender más rápidamente una búsqueda y un posible encuentro, sino porque la mayoría de sus compañeros no lo tienen porque no fueron adoptados, sino inscriptos falsamente. Acerca de esta cuestión, así reflexionaba la presidenta de la Asociación:

"Una cosa es la adopción, hecha legalmente, donde hay expediente, donde hay una historia, donde un día ese chico a los 18 años va a poder ir y ver su expediente, si quiere, y buscar su historia. Y otra cosa es cuando uno inscribe como hijo propio a un chico" [entrevista a la presidenta de la Asociación, 28 de mayo de 2011].

El expediente judicial habilita el acceso a "la historia" y si bien, como sabemos, el lenguaje judicial no resulta transparente para quienes no forman parte de ese universo discursivo, esos "papeles" contienen información que resulta sustantiva para quienes quieren conocer sus orígenes de nacimiento. Sobre las particularidades del lenguaje jurídico y las posibilidades concretas de acceder al expediente de adopción, así reflexionaba Sofía en una de las entrevistas que mantuve con ella: 
"Es muy importante el acceso, el acceso real. Cuando hablo del acceso real a los expedientes es tener el acceso a un abogado que te gestione ese pedido para que te lo pueda también explicar de esta forma de cómo fue, porque no es solamente el acceso a los papeles, el acceso a los papeles es una parte. Y aparte también viene muy condicionado porque uno no sabe dónde pedirlo, cómo pedirlo, por eso es importante lo que estamos pidiendo, ¿no? que el Estado se haga cargo, que tenga una oficina donde vos vayas y te digan, como en Abuelas [de Plaza de Mayo], bueno, ahora vas a hacer esto, después tenés este paso, este otro, establecer una forma de búsqueda, una contención. No, bueno, anda a esta dirección y si te tratan mal vemos cómo hacemos, no, ¿por qué te tienen que tratar mal, por qué te tienen que negar el acceso a tu legajo?" [entrevista con Sofía, 21 de marzo de 2012].

Si bien ser adoptado resulta favorable en términos del éxito de la búsqueda del origen, tal como señala Sofía, no está librado de escollos y trabas, fundamentalmente en las gestiones para poder conseguir el expediente. Asimismo, una vez frente al expediente tampoco resulta sencillo descifrar qué significa todo lo que allí está contenido. En este sentido, el reclamo de Sofía de "que el Estado se haga cargo, que tenga una oficina", devela la necesidad de procedimientos y protocolos que se ajusten a tal fin y por ello se opone a concebir el acceso al expediente como un mero "trámite” en Mesa de Entradas.

Ahora bien, esta importancia que adquieren "los papeles", es decir los documentos personales, para quienes quieren encontrarse con su historia biológica fue desde un comienzo un elemento recurrente en mi investigación.

\section{DOCUMENTOS PERSONALES:}

\section{CUSTODIAS FAMILIARES Y RESISTENCIAS ESTATALES}

A lo largo de mi investigación he escuchado reiteradas veces expresiones como esta: "Durante muchos años viví una historia incompleta, a la que le faltaba la verdad de mi origen, y tengo un vacío que necesito llenar. A pesar de todo el amor y cuidados que recibí, siempre faltó algo". En las narrativas de búsqueda de origen, términos como "incompletitud" y/o "vacío" se vuelven formas recurrentes de explicar y explicitar qué y cómo se sienten estas personas frente a no saber cuál es su origen biológico. ${ }^{20}$ Las razones para "buscar" son variadas, pero es posible sostener que la sensación de "vacío" que produce el "no saber" puede tornarse el común denominador en estas búsquedas. La mayoría de las

20 Janet Carsten, en su etnografía con personas adoptadas en Escocia, cuando preguntaba a los adoptados qué los motivaba a buscar a los padres biológicos, en forma habitual recibía respuestas similares a las que obtuve en mi investigación: "to know where I came from", "to be complete" o "to find out who I am” ["para saber de dónde vengo", "para estar completo”, "para saber quién soy”] (Carsten 2000b: 689). 
personas con las que he podido conversar expresan antes que curiosidad una "necesidad" de conocer los orígenes biológicos. En este sentido, esta "necesidad" y la importancia conferida a la "identidad" no pueden ser disociadas de los valores que asume el parentesco en nuestras sociedades occidentales, en donde adquieren centralidad los lazos biológicos. ${ }^{21}$

Durante el trabajo de campo junto a la Asociación pude observar la forma en que algunas personas con dudas sobre sus orígenes se contactan y luego concurren a las reuniones para realizar una consulta. En esas situaciones de consulta, las personas que inician una búsqueda sobre su origen de nacimiento se relacionan con sus "papeles" de una manera singular, existe un particular cuidado, los traen guardados en carpetas, varias bolsas de plástico y folios. "Trajiste los papeles"; "llevaste los papeles"; "lo primero es ver los papeles, sin los papeles no podemos hacer nada, tenés que traer la partida de nacimiento, por lo menos para empezar a ver, a partir de los papeles podemos empezar a saber algo", son algunas de las expresiones que se repiten en cada una de las reuniones de consulta. La forma en que esos "papeles" son manipulados también da cuenta de su importancia; cuando una persona tiene que abrir su partida de nacimiento doblada en varias partes lo hace con enorme cuidado y atención. Asimismo todos los integrantes de la Asociación manipulan los documentos con gran delicadeza y cuidado.

"Sonia está hablando sobre cómo se enteró que no era hija de las personas que la criaron, tiene en sus manos una cantidad importante de papeles, algunos amarillentos, otros no tanto, son sus documentos. Al lado de ella está José Luis, esperando su turno para plantear su búsqueda, delante de él hay una silla repleta de papeles amarillos, algunas fotos antiguas, libreta de familia, certificados de vacunación, entre otros, son sus "papeles", sus documentos dispuestos a modo casi de collage, que José Luis custodia a centímetros de distancia" [nota de campo, 31 de julio de 2010].

Esos "papeles" se guardan y se tratan con cuidado porque ellos "pueden decir cosas" sobre el origen. Además del cuidado proporcionado a los documentos, también he podido percibir que muchas de las personas que hoy buscan sus orígenes refieren que durante su infancia y adolescencia se encontraron con diferentes trabas y resistencias de parte de sus padres de crianza quienes

21 En algunas sociedades, alimentar, amamantar y/o cuidar a un niño son los actos que crean la definición de los vínculos. Por lo tanto, en esos contextos la información sobre los orígenes fisiológicos aporta un conocimiento de interés secundario. En nuestras sociedades, en cambio, debido a la centralidad dada al momento del coito, a la procreación sexuada, toda información relativa a la concepción provoca una perturbación inmediata en las relaciones y en la identidad de los individuos porque ese tipo de conocimiento está ligado a la idea de la "identidad personal” (Fonseca 2004: 29-30). 
les impedían o dificultaban tener acceso a ellos. Así lo manifestaban algunas de estas personas:

"Corina, Lucía y Rafael me cuentan que su familia no les dejaba tocar la partida de nacimiento. Lucía dice que hasta grande no pudo tener el DNI, en cambio Emilia expresa que siempre pudo tener acceso a los papeles, pero sostiene 'que eso pasa mucho y que tiene que ver con el miedo que tenían los padres de que se descubra algo en esos papeles'. Corina cuenta que la madre la fue a inscribir a la universidad y que le hacía todos los trámites, situaciones semejantes a éstas fueron expresadas también por Lucía" [nota de campo, 16 de abril de 2011].

"Lucía: A mí nunca me los dieron, jamás, nunca, ni mi partida de nacimiento, ni mis documentos me dieron, nunca, jamás.

Emilia: ¿Cuando fuiste a renovar tu documento de los 16 ?

Lucía: Mi mamá me lo renovó. Yo fui a renovar con mi mamá, [...] me acompañó mi mamá.

Soledad: ¿Y cuándo pudiste tener tu documento?

Lucía: No me lo dio, nunca me lo dio, ella... o sea, nos sacamos la foto, todo y lo retiramos, todo, y me lo sacó, no me lo dio. Cuando lo pedía me decían 'para qué lo querés', 'y, para los trámites del colegio', 'bueno, dejá que el trámite te lo hago yo, no necesitas nada, vos no necesitas, acá se te da todo'. Y ahí empezaba la discusión de que nosotros te damos todo y ahí se transfiguraba todo, ellos me trataban de dar vuelta la historia para no dármelo y saltaban con que 'te damos todo'. [...]

Soledad: ¿Y la partida de nacimiento cuando la viste?

Lucía: Cuando me enteré que era adoptada, todo me dieron 'esto, esta mierda querías, tomá, esta mierda, no ves que no tiene nada esta mierda'. Y si no tiene nada para qué me lo negaste... Me los tiraron por la cabeza.

Soledad: Bueno, pero te los quedaste.

Lucía: Sí, me los quedé pero no decía nada, no decía nada, decía que yo era hija de ellos" [entrevista informal a integrantes de la Asociación, 28 de abril de 2012].

"Sandra - persona que llega a la reunión a consultar - cuenta que se enteró a los 40 años que era adoptada, por una amiga. Una integrante de la Asociación le pregunta: pero inunca necesitaste la partida para ningún trámite? No, dice Sandra, antes no se precisaba tanto, ahora se pide para todo, para el pasaporte, para todo y ahí te das cuenta. Sandra dice 'no, la última vez que usé la partida fue para la compra de la casa, pero fue antes de los 40. Y cuando nos casamos, como los dos trabajábamos fue mi mamá a hacer los trámites al registro civil, entonces ella andaba con la partida' " [nota de campo, 29 de octubre de 2011]. 
"Mucha gente viene y te dice, gente grande, 'ah, yo nunca vi mi partida'. O 'ella [madre de crianza] no me deja tener mi partida' " [entrevista informal a integrantes de la Asociación, nota de campo, 28 de abril de 2012].

Además de la dificultad para acceder a sus documentos durante su infancia o su adolescencia, algunas de estas personas - como Corina, Sandra, Rafael y Lucía - sostienen que esto se extendió incluso hasta su adultez. En los casos donde el acceso a los documentos estaba restringido existió una custodia de los documentos, y ello puede relacionarse con el temor de los padres de crianza acerca de que su lectura develara el status adoptivo, es decir que se rompa "el secreto" y se sepa "la verdad". Así me lo comentaba la presidenta de Asociación en una entrevista informal en el 2012: “Tenían miedo que ahí se pudiera descubrir algo, ellos no lo sabían, sabían que habían hecho algo que estaba mal, entonces pensaban que se podía ver".

Estos padres de crianza, sin entender con exactitud qué podían develar esos documentos, y aunque en ocasiones sabían que "no decían nada", los retenían y no se los entregaban ni mostraban a sus hijos. Si bien no se encontraba nada en esos "papeles", estos eran los objetos que condensaban que algo "estaba mal", es decir materializaban el hecho de la inscripción falsa.

Por el contrario, en otros casos, como el de Aldana y Emilia, no se verifica esta práctica de custodia de los documentos por parte de sus padres de crianza, ellas manifiestan que siempre tuvieron acceso a sus "papeles".

"En otras historias, de otros compañeros, ellos dicen 'No, porque yo nunca tuve acceso a mi partida de nacimiento, nunca tenía acceso a mis documentos'. Yo todo el tiempo miraba mi partida de nacimiento, sabía que figuraba, que yo había nacido el 15 de noviembre a las 20.30hs, que firmaba $X$, que era la médica, que estaba el nombre de mi mamá y de mi papá, no había otra cosa más, no había nada que me llamara la atención, o que dijera "Uy, no, esto es re turbio". Y mi DNI también, tenía siempre acceso, es más, de hecho yo siempre fui la encargada de hacer trámites míos escolares, entonces yo era la que me llevaba la partida de nacimiento, el DNI o lo que sea, sabía bien donde estaban guardados, no es que era una información restringida para mí. Yo sabía que estaban en el segundo cajón de la cómoda de la pieza de mis padres, yo podía ir, agarrarlo, verlo, no había mucha cosa de decir 'eso estaba vedado para vos, no lo toqués' " [entrevista a Aldana, 26 de abril de 2012].

"Yo fui al secundario a hacer mis trámites, la que hacía los tramites era yo, mi mamá me acompañó, pero la que hacía todo era yo. Llevé la partida [de nacimiento], a mí no me la negaron nunca, por eso digo que mi papá era inteligente, porque en la partida qué iba a haber, nada. Mucha gente 
que le esconde la partida, ¿para qué, si no hay nada en esa partida? Es el sentimiento de culpa que tienen" [entrevista a Emilia, 24 de noviembre de $2011]$.

Mientras algunos padres de crianza entregaban los documentos sin reparos, otros los ocultaban fervorosamente. Entonces ¿de qué nos hablan y con qué se vinculan estas diversas formas de relacionarse con los documentos?

La variedad de documentos emitidos por el Estado hace legibles y cartografiables a los sujetos y las poblaciones, tal como señaló James Scott (1998), y así facilitan tanto tareas de vigilancia y control, como de asistencia y provisión. En palabras de DaMatta ellos son las manifestaciones concretas de la "mano visible del Estado" en las sociedades modernas. Para este autor, los documentos son "vehículos que materializan el lugar que ocupamos y lo que somos en el sistema, estableciendo nuestros derechos y deberes, nuestros límites y obviamente nuestro poder, autoridad y prestigio" (2002: 46) y "aunque sean emitidos por el Estado los documentos son fetichizados, teniendo un valor intrínseco, efectivamente mágico" (2002: 52). En una línea analítica similar, el antropólogo Gastón Gordillo (2006) expresa la sorpresa que le causaba que algunos tobas - un pueblo originario del oeste de la actual provincia argentina de Formosa - durante su trabajo de campo le mostraran orgullosamente sus documentos de identidad, y cómo los conservaban en bolsas de plástico y hablaban de ellos como posesiones realmente muy valiosas. Estas actitudes, para Gordillo, revelan "una preocupación por la materialidad de los documentos que está configurada por la memoria de haber sido privados de ellos durante décadas" (2006: 169). Por ello afirma que la gente indígena "ve sus documentos de identidad no sólo como símbolos, sino como algo más: como objetos potentes que, por sí mismos, configuran el resultado de procesos sociales" (Gordillo 2006: 171 ). En efecto, la potencia asimilada a estos documentos se asocia a la visión de la palabra escrita como símbolo de poder de quienes habían conquistado esa región.

Esa indagación devela una de las múltiples significaciones que pueden tener los documentos y nos recuerda que estos objetos, documentos de identidad y partidas de nacimiento, no poseen valor "sin las relaciones sociales que los producen y les dan significado como símbolos de algo más. El poder que la gente le atribuye a los documentos yace allí, en esas relaciones y convenciones, antes que en su materialidad" (Gordillo 2006: 192). Para quienes buscan sus orígenes, los documentos adquieren importancia más allá de su materialidad, porque ellos condensan y resultan de las prácticas vinculadas al secreto, la mentira y el ocultamiento por parte de sus padres de crianza y de las oficinas estatales.

Así, por un lado, encontramos el cuidado conferido a los documentos por quienes buscan sus orígenes, con prácticas tales como ponerlos en bolsas de 
plástico y guardarlos cuidadosamente, y por otro lado, las prácticas de custodia, que dan cuenta de lo mucho que representan y condensan esos papeles para los padres de crianza, pues muchos de ellos temen que se descubra "la verdad" si sus hijos tienen acceso a ellos.

Los documentos personales adquieren diferentes sentidos y valoraciones, para quienes buscan podrían potencialmente develar algo de sus nacimientos, al mismo tiempo que se encuentran asociados a prácticas relativas al secreto, la mentira y el ocultamiento. De este modo, ellos se vuelven símbolo de aquello que se pretende negar. Así esconderlos y retenerlos pareciera formar parte de los esfuerzos por ocultar "la verdad" de los orígenes y, al mismo tiempo, el hecho delictivo que cometieron los padres de crianza. ${ }^{22}$

Por otra parte, muchas de las personas que inician una búsqueda encuentran que en ocasiones suele ser el Estado, mediante sus funcionarios, quien custodia - según sus percepciones - desmedidamente sus documentos. En varias oportunidades, he escuchado referencias y quejas respecto de las dificultades a las que estas personas se enfrentan cuando van a realizar pedidos a dependencias estatales sobre sus documentos, en donde se encuentran con funcionarios que "no comprenden por qué uno está buscando eso [un documento]" o "te tratan mal" o "ponen cualquier excusa, que los libros [de parto] no están, que el archivo se inundó, que venga otro día”. Así me lo comentaban durante las reuniones de la Asociación:

"Los expedientes son de la gente. Las trabas las ponen los empleados públicos, pero ellos son los que los guardan, no son de ellos" [nota de campo, 31 de marzo de 2012].

"Los empleados públicos te negaban los archivos, los expedientes, los legajos, como si fueran de su propiedad. Este trabajo de tantos años hizo que fueran aprendiendo que esos archivos y expedientes son de la gente, no de ellos, ellos son los que los guardan, nada más" [entrevista a la presidenta de la Asociación, 1 de octubre de 2011].

Más allá de que para algunos miembros de la Asociación los documentos hayan estado siempre disponibles, y que para otros haya existido una forma de custodia sobre ellos tendiente a no develar el secreto sobre el origen, todos manifiestan la importancia de que el Estado, mediante sus oficinas, habilite el acceso a los documentos necesarios para viabilizar las búsquedas. Frente a las

22 Asimismo, existen otras formas en que los padres de crianza ocultan "la verdad", tales como contestar con evasivas y mentiras a las dudas que estas personas manifiestan, en ocasiones afirmando que esas dudas son "una locura" que "alguien les metió en la cabeza"; o tramitar verdaderos pactos de silencio con el resto de los familiares, mediante amenazas del tipo "si le contás la verdad me mato". 
dificultades que encuentran con los agentes estatales sostienen que a estos les resulta complejo comprender las características que asumen sus búsquedas, porque no les sucede lo mismo que a ellos. Por esa razón, esos agentes no pueden comprender la importancia que un simple trámite, como es el pedir un documento, encierra en el proceso de búsqueda.

"Se ve que como no lo sienten... Es diferente que un organismo como nosotros que nos pasa lo mismo, los organismos del Estado no sienten" [nota de campo, 31 de marzo de 2012].

"Los funcionarios deberían estar preparados para no emitir juicios morales sobre las personas que van a consultar. Si no pueden suspender sus prejuicios no pueden realizar su trabajo" [nota de campo, 18 de mayo de 2012].

Esta dificultad que encuentran en el acceso a sus documentos es traducida e interpretada por los integrantes de la Asociación como una imposibilidad de parte de los organismos estatales de comprender este tipo de búsquedas. Una percepción semejante recoge Claudia Fonseca de los integrantes de la asociación Filhos Adotivos do Brasil, a la que ha denominado "resistencias de las burocracias". Los integrantes de esa asociación manifiestan dos quejas, por un lado "que la familia adoptiva les esconde la 'verdad' de su status adoptivo [...] y un segundo tipo de queja [...] que refiere a las resistencias de las burocracias en colaborar en la búsqueda por informaciones" (Fonseca 2010: 502). En este sentido la autora plantea: "mis interlocutores enfatizan lo que consideran como la indiferencia y hasta hostilidad de varios 'porteros' (autoridades en los hospitales, en los registros y en los juzgados) que controlan el acceso a los archivos" (Fonseca 2010: 504). A pesar de contar con legislaciones, que refieren al acceso al expediente para los adoptados y a la defensa integral del derecho a la identidad, los "adoptados" argentinos y brasileños continúan dependiendo de la "buena voluntad" de los funcionarios que se encargan de la documentación relativa a sus orígenes, situación que expone el desafío de "diseñar procedimientos administrativos que garanticen la implementación de derechos a pesar de las sensibilidades variables de los administradores" (Fonseca 2010: 516), un desafío que, tal como pude advertir durante mi investigación, ocupa un lugar central en la agenda de los activistas de este campo.

Los documentos, entonces, adquieren un valor central y se convierten en poderosos objetos para todos los actores involucrados en las búsquedas de origen: para aquellos padres de crianza que los guardaron celosamente a fines de no develar el secreto sobre el origen de los niños que han anotado como propios; para las personas que actualmente buscan su origen y que los manipulan con enorme cuidado porque en ellos quizás puedan "descubrir" algo acerca de ese origen desconocido, y para los agentes estatales, que en miras a cumplir 
con su "deber" en ocasiones se muestran reticentes a entregarlos. El conjunto de prácticas de estos diversos actores pueden ser interpretadas teniendo presente la noción de "opresión burocrática" (cf. Reis 1998, cit. en Ferreira 2013; DaMatta 2002). El carácter opresor deviene justamente de una de las características más significativas de los documentos: ellos son imprescindibles. Al mismo tiempo que los ciudadanos se ven obligados a tener una variedad de registros y comprobantes documentales incontables, los burócratas también son alcanzados por esta exigencia que, tal como analiza Letícia Carvalho de Mesquita Ferreira (2013), sin duda implica mucho más que "llenar papeles".

\section{"LEGALES PERO ILEGÍTIMOS": \\ LOS DOCUMENTOS EN LAS FALSAS INSCRIPCIONES}

Como señalé anteriormente, una persona adoptada puede acceder al expediente en el que se tramitó judicialmente su adopción y - a pesar de los inconvenientes que manifiestan - conocer detalles sobre su historia. Sin embargo, casi la totalidad de las búsquedas que conocí durante mi trabajo de campo corresponden a personas que han sido inscriptas falsamente. Inscribir como propio a un hijo ajeno es un delito y por lo tanto es ilegal, sin embargo resulta complejo realizar la misma afirmación sobre los documentos (partida de nacimiento, DNI) que resultan de esas inscripciones. Si bien las partidas de nacimiento tienen datos falsos, en la medida en que figuran como padres biológicos personas que no lo son, éstas son utilizadas sin ningún inconveniente por estas personas en sus vidas cotidianas (léase identificación en una variedad de trámites, como casamientos, inscripciones escolares, entre muchos otros). Es decir, el hecho de que las partidas de nacimiento contengan datos falsos no las vuelve inútiles en tanto documento de identificación para la vida en sociedad.

Cuando les pregunté, a diferentes personas que fueron inscriptas falsamente, sobre las características de sus documentos, me explicaron que sus partidas de nacimiento son "legales pero ilegítimas". En la Asociación a quienes vienen a consultar también les explican esta distinción. Es decir, son partidas auténticas porque cumplen con el procedimiento rutinario de inscripción, y funcionales ya que sirven para identificar a la persona y para hacer cualquier trámite que requiera ese documento, pero su contenido no es veraz, pues no se corresponde con la realidad. Por lo tanto, según los integrantes de la Asociación, es "ilegítimo". Así explican las particularidades que tienen sus partidas de nacimiento en los casos de falsas inscripciones:

"Mirá, nosotros siempre decimos que las partidas [de nacimiento] no son legítimas, porque no reflejan nuestra realidad" [respuesta a una persona que acudió a la Asociación para iniciar una búsqueda, nota de campo, 11 de diciembre de 2010]. 
"Las partidas son legales porque cumplen con los requisitos: nombre de los padres, DNI de los padres, lugar de nacimiento, certificado médico, depende de la época, en algunos momentos no se pedía. El certificado médico es ilegítimo porque están certificando algo que no sucedió, al igual que quienes declaran ese nacimiento porque declaran algo que es falso" [entrevista informal a la presidenta de la Asociación, 21 de abril de 2012].

"En la partida de nacimiento figurás como si fueras hijo biológico de esa familia, porque fue alterada, digamos, la partida es legal pero ilegítima porque no refleja la verdad, pero la gente dice mis papás adoptivos, a pesar de que adopción es otro tema, porque es una cosa legal, y vos teniendo una adopción podes buscar tu historia biológica, a menos que hayas sido abandonado en la Casa Cuna o en un lugar que te dejaron sin ningún dato, están los datos, al menos de la mamá, porque hasta cuando era una menor, si uno busca el certificado de nacido vivo, si es que tenés la suerte de que esté todo, en los archivos están los datos de esa mamá. En cambio los que fuimos anotados como hijos propios no tenés donde buscar, dependés de lo que saben los demás" [entrevista grupal a los integrantes de la Asociación, nota de campo, 28 de mayo de 2011 ].

Esta distinción resulta difícil de entender en un primer momento, es decir, cuando la persona inicia su búsqueda, llega a las reuniones y realiza la exposición de su propia historia, situación que en todos los casos genera una fuerte emoción, ya que las personas se angustian y en ocasiones lloran.

Los términos legal y legítimo, como indiqué, emergen en los dichos de los integrantes de la Asociación en relación a un mismo documento: la partida de nacimiento. A partir de la experiencia de trabajo de la Asociación, el primer paso de la búsqueda implica examinar la partida de nacimiento para saber si hubo una adopción o presumir si hubo una inscripción falsa. Los partos en domicilio y las inscripciones fuera de término son indicadores de potenciales inscripciones falsas. Pero encontrar este tipo de datos requiere de la adquisición de una particular clave de lectura que permite des-cubrir estas cuestiones, tal como dice la presidenta de la Asociación:

"Los papeles... Es decir, los documentos están bien, tienen los datos que tienen que tener, pero igualmente se pueden descubrir verdades en los documentos, indicios de que hubo una inscripción falsa, anotaciones fuera de término, partos en domicilio, y otras cosas" [conversación con integrante de la Asociación, nota de campo, 21 de mayo de 2011].

Para quienes se acercan a consultar por primera vez resulta incomprensible cómo un documento puede ser legal si contiene datos que no son 
precisamente verdaderos, que no condicen con la realidad, tal como fue el caso de Jorge:

"Jorge toma su partida de nacimiento y dice: 'Pero acá está escrito y dice que mis padres son Juana y Pedro'. [Niega con la cabeza varias veces]. Un integrante de la Asociación le dice: "Yo sé que al principio cuesta entenderlo, pero este papel - agarra la partida de nacimiento - es legal pero no es legítimo. ¿Entendés? No es trucho, es legal pero no refleja la verdad" " [consulta de Jorge que busca conocer su origen biológico, nota de campo, 31 de julio de 2010].

En varias oportunidades me pregunté por qué los integrantes de la Asociación se referían a las partidas como "legales e ilegítimas" y no sencillamente como falsas. El término legítimo refiere a aquello que es conforme a la ley o el derecho; una segunda acepción aplica "a las cosas que son realmente lo que se dice que son o lo que expresa el nombre que llevan, y no una imitación o falsificación" (Moliner 2007). Algo ilegítimo refiere a aquello que no es conforme con la ley o es falso, que las partidas sean legales e ilegítimas llamaba mi atención, pero no atendiendo a la precisión o imprecisión de los términos respecto de esos documentos, sino por la elección de esos términos y no de otros. ${ }^{23}$

Con el tiempo, a medida que transcurrían las reuniones de la Asociación, escuchando de forma recurrente la apelación a ambos términos comprendí que el binomio "legal e ilegítimo" es el resultado de una construcción que hace la Asociación para transmitir las características que asumen los documentos - partidas de nacimiento - en los casos de quienes fueron inscriptos falsamente. Es una explicación elaborada para explicarse y explicar la singular característica que asumen estas partidas: son funcionalmente útiles (de hecho les han otorgado una identidad con la que han vivido todos estos años) pero a la vez no son "verdaderas", no tienen legitimidad.

Asimismo, la apelación a los términos "legal" e "ilegítimo" para caracterizar a las partidas de nacimiento producto de las falsas inscripciones encuentra sintonía con el interés que tienen los activistas que buscan sus orígenes de nacimiento en distinguir la adopción en tanto práctica "legal" de la inscripción falsa que es un "delito". Así, en ambas acciones, es decir cuando explican cómo fueron sus inscripciones y cuáles son las características de sus documentos producto de esa inscripción de la filiación, hacen uso de un lenguaje que alude al universo de lo jurídico. 
VOLVER LEGÍTIMOS LOS DOCUMENTOS:

\section{RECTIFICAR LA FILIACIÓN EN LAS FALSAS INSCRIPCIONES}

Si bien los documentos de estas personas son "legales", muchos me han referido que tienen la aspiración de que los datos allí vertidos reflejen la "verdad", lo que implicaría rectificar sus filiaciones, un trámite que, como veremos a continuación, no resulta sencillo.

Como indiqué, la filiación de las personas que han sido inscriptas falsamente ha sido fraguada. Si bien las dimensiones biológica y jurídica que componen la filiación se articulan, en la mayoría de los casos, de forma que parecen una sola pieza (Martínez 2010: 298), en estos casos las dimensiones comportan piezas diferentes y la posibilidad de rearticularlas mediante una rectificación de la filiación resulta, como veremos en los casos de Lucía, Emilia y Sabrina, poco probable.

Antes de abordar los casos, conviene señalar que al igual que para los casos de niños desaparecidos que fueron inscriptos como hijos propios, en las inscripciones falsas de estas personas los documentos son apócrifos. En su investigación con niños - hoy adultos - apropiados durante la dictadura militar, Sabina Regueiro señala que sus documentos son apócrifos "en un sentido particular: muchos de ellos son auténticos, porque formalmente cumplieron los procedimientos habituales, legales, pero son falsos en cuanto a su contenido, en relación a la filiación reflejada en el papel, así como las fechas y lugares que tampoco corresponden a la realidad. En estos casos se pudo saber que no eran veraces a partir del análisis genético de los niños allí inscriptos, que determinaron que los documentos no decían la verdad" (Regueiro 2010: 49).

Sucede que para las búsquedas de origen que emprenden los integrantes de la Asociación o quienes se acercan a consultarlos (en las que lo importante no es solamente demostrar la falsedad de la inscripción sino encontrar a los padres biológicos), las posibilidades de cotejar la filiación mediante estudios genéticos son muy escasas. Solo se han podido realizar pruebas de este tipo, en los casos en los que las personas encontraron datos sobre una posible madre, y/o excepcionalmente padre, o en aquellos casos en que una madre o padre se han acercado buscando a un hijo dado en adopción. De lo contrario no es posible tener con quien cotejar el resultado del $\mathrm{ADN}$, sólo se demuestra que no se es hijo biológico de las personas que lo inscribieron como tal, como le sucedió a Sabrina.

Ahora bien, Lucía forma parte del pequeño porcentaje de personas que conocí durante mi investigación y que han podido cotejar su ADN con posibles progenitores. Ella fue inscripta falsamente como hija biológica en 1976 y en una ocasión en la que entrevistaron a los integrantes de la Asociación para una revista de amplia tirada y salieron sus fotografías, una mujer - que estaba buscando a su hija nacida en 1976 - vio la foto de Lucía y supuso que podría 
ser su hija, por ello se acercó a la Asociación y luego se realizaron un estudio genético que dio negativo.

Para quienes buscan sus orígenes la tecnología del ADN se configura como un medio para acceder a una verdad entre "tantas mentiras", como señalan. Si bien la mayoría no puede realizarse esos estudios (porque no tienen con quien comparar), lo cierto es que lo harían si pudieran, y ello se relaciona con la "creciente importancia legal del test de ADN, y la posibilidad de saber "la verdad real” (Fonseca 2004) que en nuestra concepción genealógica del parentesco se cifra fuertemente en la biología. También cabe señalar que en Argentina - a diferencia por ejemplo del caso brasilero - el uso del test de ADN se asocia a la localización y restitución de los niños que fueron apropiados durante la dictadura militar y por ende al trabajo político realizado por Abuelas de Plaza de Mayo en la búsqueda de sus nietos (Regueiro 2010). De este modo, el test del ADN y la producción documental, entendidos en tanto tecnologías de saber-poder (Scott 1998; Foucault 2006), en este campo emergen con distintas valoraciones; mientras que los documentos personales "pueden" decir algo de "la verdad" sobre los orígenes y ser una "vía" para indagar, el test se configura como el pasaporte a "la" verdad y es por ello que muchas de estas personas quisieran poder tener con quien cotejar su información genética.

En suma, si estas personas pudieran realizarse estudios comparativos de ADN con posibles progenitores sería mucho más simple rectificar sus filiaciones y volver legítimos y legales sus documentos, pero al no tener la posibilidad de cotejamiento se dificulta esa rectificación, tal como se evidencia en la historia de Emilia. ${ }^{24}$

"Si voy a un juez y le digo que éstos no son mis padres [en referencia a quienes figuran como tales en su partida de nacimiento], tengo que hacerme un ADN y eso va a confirmar que no son, pero entonces, ¿quién soy? Porque no tengo nadie con quien comparar" [entrevista informal a Emilia, 21 de abril de 2012].

Tal como señala Emilia, en estas búsquedas se torna muy complejo volver veraces o "legítimos" esos documentos. Durante la misma entrevista me advirtió sobre otros inconvenientes. Si se inicia una presentación judicial, el juez solicitará pruebas que acrediten las razones por las que supone que quienes figuran en su partida no son sus padres biológicos. La prueba (judicial) en este tipo de casos se basaría en comentarios e hipótesis tejidas a partir de relatos de terceros, tal como me decía Emilia: "Nosotros no tenemos pruebas, son

24 Si bien pocas personas pueden realizarse estos estudios, cabe señalar que los gastos derivados de éstos, que son onerosos, son cubiertos por las personas interesadas en ese cotejamiento, un elemento que dificulta aún más el escenario de la búsqueda. 
rumores, entonces es más difícil”. Si este primer obstáculo puede superarse, existe una segunda instancia de cotejamiento de datos genéticos con los padres de crianza para demostrar que no hay vínculo biológico. Los padres de Emilia fallecieron y fueron cremados, de este modo es imposible confirmar que no hay lazo biológico con las personas que figuran como padres en su partida de nacimiento. En otros casos la dificultad radica en que los padres de crianza están vivos y las personas temen por la represalia judicial que pueda recaer sobre ellos.

Josefina Martínez advierte que "[las] filiaciones pueden ser revisadas y rectificadas en procesos en los cuales el sujeto constituido a partir de la filiación originaria toma en sus manos las herramientas sociales y jurídicas a su alcance para corregir alteraciones y volver a construir su filiación en una nueva clave" (2010: 287). Emilia, a pesar de saber que su filiación jurídica no se corresponde con su filiación biológica y querer construir su filiación en una nueva clave, no puede realizar acciones en pos de rectificar esa situación. Suponiendo que Emilia pudiera cotejar el ADN con sus padres de crianza, ella señalaba un dato sugestivo: "Si yo desacredito mi partida, me quedo sin nombre."

Fue este mismo dilema el que se le presentó a Sabrina, cuando luego de pedirle en reiteradas ocasiones y de diversas maneras a sus padres de crianza que le dijeran "la verdad", judicializó su caso. A partir de una presentación judicial, no sin dificultades, logró que sus padres de crianza se realicen el estudio genético que determinó que no existe lazo biológico. Así me lo contaba:

"Sabrina: [Después del ADN] fue un fallo breve pero sustancioso, que la seguridad jurídica no pueda estar basada en la ficción, eso es fundamental, porque ella [jueza] me da lugar a que yo impugne esa partida. Porque generalmente impugnas cuando decís no es éste porque sabes que es otro, pero acá no son estos porque el ADN dice que no son estos, ah ìy quienes son?, ah, yo que sé, no sé. O sea, yo estoy sin padres ahora. [...]. Y se tuvo que hacer una anotación al margen de la partida, donde se hace constar que esos no son mis padres, se remite al fallo tal, no se explica todo, sino que se remite al fallo.

Soledad: ¿Y con el apellido qué decisión tomaste?

Sabrina: Yo por ahora mantengo el apellido en la partida sí, sí, me lo podría sacar.

Soledad: ¿Y en ese caso qué te ponés?

Sabrina: Nada, nada. Ninguno. Porque te dicen 'no podés estar sin apellido', ah, entonces podés tener cualquiera [se refiere a un apellido común como Pérez, Martínez], me pongo Rockefeller [se ríe]" [entrevista a Sabrina, ciudad de Buenos Aires, 11 de abril de 2014]. 
Si bien su nombre fue elegido por quienes la criaron - a quienes llama por sus nombres de pila -, me dice "yo soy Sabrina Rosario", dando a entender que no podría cambiarse el nombre, es decir elegir un nombre nuevo. Aunque usa el apellido en cuestiones formales, se presenta con sus dos nombres, utilizando su segundo nombre a modo de apellido. Zonabend señala que "por lo que refiere a nuestros nombres, su transmisión a veces obedece a reglas tan rigurosas que permiten apreciar rasgos muy significativos de nuestra realidad social" (1986: 30), y menciona la costumbre de ponerle al primogénito el nombre del abuelo paterno, lo que denota la importancia que tienen en nuestra cultura las posiciones genealógicas (cf. Van Gennep 1986 [1909], cit. en Zonabend 1986: 30).

El nacimiento, el matrimonio, es decir los cambios de status significativos en la vida de una persona, implican nuevas denominaciones y ocasionalmente un cambio de nombre. Muchas veces, el hecho de des-cubrir la mentira sobre los orígenes genera en algunas de estas personas prácticas que tienden a hacer modificaciones con respecto a sus nombres y apellidos. He observado que en general siguen usando sus nombres de pila, pero suelen omitir el apellido, como indiqué en el caso de Sabrina. Lo mismo sucedió en el caso de Yamila, que en vez de utilizar su apellido se refiere a sí misma como "Yamila de Orígenes" (nombre de la ONG que preside). En este sentido, el descubrimiento de que sus padres de crianza les mintieron opera como un cambio de status en donde, en ocasiones, se observa la negación del apellido.

Como demostré, Sabrina pudo impugnar la paternidad de quienes creyó, durante más de cuarenta años, que eran sus padres biológicos y logró imprimir en su partida de nacimiento - en esa pequeña anotación marginal - el resultado de su lucha personal por demostrar "que no estaba loca" que "era verdad" que ellos no eran sus padres. Si bien Sabrina logró rectificar su filiación jurídica aún no supo nada de su origen biológico, su filiación biológica está "en suspenso", una situación que se repite en estos casos.

\section{CONSIDERACIONES FINALES}

Para quienes han sido "adoptados entre comillas", es decir que fueron inscriptos falsamente, buscar sus orígenes biológicos resulta un camino repleto de escollos y dificultades. Aun cuando también enfrenten dificultades y resistencias, no sucede lo mismo para quienes fueron adoptados "como Dios manda" - así lo expresaba una entrevistada -, es decir, mediante un trámite legal, ya que pueden acceder a su expediente de adopción.

Como fue señalado por Zonabend (1986), la relación biológica no es en absoluto necesaria para la creación de un vínculo de parentesco y afecto y para la creación de una familia. Esta premisa es transparente para quienes buscan sus orígenes, sin embargo, más allá del tipo de relación que hayan forjado 
con quienes los criaron, consideran necesario - y exigen tanto a sus padres de crianza como al Estado - que se les garantice la verdad sobre sus orígenes biológicos.

Ahora bien, la centralidad que adquieren la legitimidad y la legalidad de los documentos, para las personas que buscan sus orígenes, también puede comprenderse teniendo en cuenta que la "importancia de esos papeles deriva de la fuerza de una profunda retórica legalista, una retórica centrada en el Estado" (DaMatta 2002: 61).

Como he demostrado a lo largo del artículo, la relevancia atribuida a los documentos personales se relaciona con que en ellos se pone de manifiesto que la filiación biológica no se corresponde con la filiación jurídica; la no correspondencia entre ambas dimensiones (biológica y jurídico-social) emerge como intolerable porque evidencia que algo en sus parentescos "no está bien", en tanto según nuestra forma de concebir las relaciones de parentesco ambas dimensiones inexorablemente deben coincidir. Así, partidas de nacimiento y documentos de identidad para estas personas adquieren un status contradictorio, las identifican y al mismo tiempo sus datos no dicen "la verdad", son documentos con una doble condición, "legales e ilegítimos", como ellos dicen. Esos "papeles", señala Mariza Peirano (2006, 2009) en referencia a los documentos de identidad, reconocidos y regulados por el Estado son exclusivos y nos identifican como únicos.

"El vínculo entre la persona y el documento que la identifica no es apenas de representación, es también de contigüidad y/o extensión. [...] En algunas situaciones el documento parece ser más que un objeto que concede ciudadanía, completa al individuo de forma más profunda" (Peirano 2006: 146, 150).

Por su parte, DaMatta (2002: 40, 57), señala que los documentos de identidad tienen un significado emocional en las sociedades modernas y pueden ser pensados en tanto dones valiosos porque son inalienables. En una misma línea, Ferreira indica que "los documentos funcionan no como artefactos estériles y autónomos, y sí como objetos materiales de derecho, de la administración y del gobierno capaces de producir diferentes efectos y engendrar múltiples afectos y relaciones" (2013: 42, citando Navaro-Yashin 2007: 95). En suma, teniendo presente estas perspectivas de análisis, los vínculos que estas personas establecen con sus documentos pueden interpretarse a la luz de términos tales como la contradicción, la incertidumbre y la ambigüedad. La mayoría de estas personas transcurre sus vidas con estos documentos auténticos, útiles, funcionales para la variedad de trámites que requiere una vida en sociedad y falsos en su contenido. Esta situación nos recuerda que esos "papeles" son símbolos de identidad y a la vez dispositivos que, por su potencia, son capaces 
de construir realidades jurídicas y sociales, en estos casos realidades jurídicas que no condicen con la realidad biológica.

DaMatta sugiere que la preocupación por los "papeles" revela que estos indican que quienes son sus portadores son "ciudadanos plenos" o "completos", esto es "personas con sus documentos en orden" (2002: 53). Tal como señalé, quienes buscan sus orígenes, en efecto, se sienten "incompletos" y "vacíos" por "no saber", y las características de sus documentos personales refuerzan estas valoraciones en la medida en que ellos se vuelven objeto, elemento y símbolo del delito cometido por sus padres de crianza y de la ambigüedad e incertidumbre sobre sus orígenes. Si bien tienen sus documentos, son documentos "ilegítimos" e "incompletos", en la medida en que carecen de la "verdadera" información sobre sus orígenes.

Por último, quisiera referirme a las formas que asume la filiación de estas personas. En nuestro modelo de parentesco euroamericano (Schneider 1984), la forma de comprender la filiación - es decir donde el padre reconoce e inscribe a los hijos - se ancla en la tradición del derecho romano: "cada uno empieza su carrera bajo la dependencia jurídica de otro. Ese otro no es el mundo en general, ni algún ser ontológico, ni dios. Es producto de una institución. Existe de derecho ya sea como amo, dominus, o bien como padre, pater. Ese otro sujeto es el padre" (Thomas 1999: 118-119, cit. en Martínez 2010: 308).

Para estas personas, la tarea de buscar el origen de nacimiento implica remontar la filiación, es decir, invertir el camino descendente - de padres a hijos - que ésta usualmente adquiere en nuestra sociedad. La filiación se presenta, entonces, como una suerte de puzzle que debe ser rearmado. Los sujetos remontan el camino de su filiación establecida invirtiendo, de alguna manera, la filiación en el sentido clásico otorgado por el derecho romano (Thomas 1999); hay un recorrer en sentido inverso, es decir, de hijos a padres.

Como desarrollé, inscribir falsamente a un hijo ajeno redunda en una filiación sustitutiva (Fonseca 1998) que anula el rastro del lazo biológico. En estos casos, la filiación jurídica de estas personas ha sido fraguada y tienen su filiación biológica en suspenso, por ello es que demandan al Estado por legislaciones, protocolos y oficinas que se ocupen de sus búsquedas de origen.

En suma, la forma que asume la filiación de quienes buscan sus orígenes pone en evidencia "la manipulación social de que es objeto el engendramiento biológico" (Mathieu 1977: 44, cit. en Zonabend 1986: 71), y también cómo en esa manipulación social, de la que es producto la filiación, pueden ocupar un lugar central los secretos, el ocultamiento y las mentiras, que no sólo se tramaron al interior de las familias que quisieron a un hijo "como si" fuese biológico, sino que se hicieron extensivas a las burocracias estatales, que en el pasado también fueron responsables de fraguar datos, hechos y documentación y que en la actualidad se resisten a entregar los documentos necesarios para saber "algo" sobre el origen de nacimiento de estas personas. 


\section{BIBLIOGRAFÍA}

AMORÓS, Pere, Jesús FUERTES, y Isabel PAULA, 1996, "La búsqueda de los orígenes en la adopción", Anuario de Psicología, V (I): 107-119.

CADORET, Anne, 2004, "Pluriparentesco y familia de referencia", en Diana Marre y Joan Bestard (comps.), La Adopción y el Acogimiento: Presente y Perspectivas. Barcelona, Universitat de Barcelona, 273-283.

CADORET, Anne, 2009, "Parentesco y figuras maternales: el recurso a una gestante subrogada por una pareja gay", Revista de Antropología Social, 18: 67-82.

CARSTEN, Janet, 2000a, Cultures of Relatedness: New Approaches to the Study of Kinship. Cambridge, Cambridge University Press.

CARSTEN, Janet, 2000b, "Knowing where you've come from: ruptures and continuities of time and kinship in narratives of adoption reunions", Royal Anthropological Institute, 6: 687-703.

DaMATTA, Roberto, 2002, "A mão visível do Estado: notas sobre o significado cultural dos documentos na sociedade brasileira", Anuário Antropológico, 99: 37-64.

DUVA, Jesús, y Natalia JUNQUERA, 201 1, Vidas Robadas. Madrid, Aguilar.

FERREIRA, Letícia Carvalho de Mesquita, 2013, “'Apenas preencher papel': reflexões sobre registros policiais de desaparecimento de pessoa e outros documentos”, Mana, 19 (1): 39-68.

FONSECA, Claudia, 1998, Caminos de Adopción. Buenos Aires, Eudeba.

FONSECA, Claudia, 2004, "A certeza que pariu a dúvida: paternidade e DNA", Revista de Estudos Feministas, 12 (2): 3-34.

FONSECA, Claudia, 2009, "Pertencimento de família e hierarquia de classe: segredo, ruptura e desigualdade vistos pelas narrativas de adotados brasileiros", Journal of Latin American and Caribbean Anthropology, 14 (1): 92-1 14.

FONSECA, Claudia, 2010, "Direito às origens: segredo e desigualdade no controle de informações sobre a identidade pessoal”, Revista de Antropologia, 53: 493-526.

FOUCAUlT, Michel, 2006, "Clase del 1. ${ }^{\circ}$ de febrero de 1978", en Michel Foucault, Seguridad, Territorio, Población. Buenos Aires, Fondo de Cultura Económica, 107-139.

GESTEIRA, Soledad, 2013, “Buscar el 'origen biológico’: parentesco y familia en organizaciones de personas 'adoptadas'”, KAIROS: Revista de Temas Sociales, 18 (33): 1-25.

GESTEIRA, Soledad, 2014, "Más allá de la apropiación criminal de niños: el surgimiento de organizaciones de personas 'adoptadas' que buscan su 'identidad biológica' en Argentina", Runa, 35 (1): 61-76.

GODELIER, Maurice, 1993, “Incesto, parentesco y poder”. El Cielo por Asalto, 5, 99-1 15.

GODELIER, Maurice, 2014, "Siempre se necesita más que un hombre y una mujer para hacer un hijo", en Maurice Godelier, En el Fundamento de las Sociedades Humanas: Lo Que Nos Enseña la Antropología. Buenos Aires, Amorrortu, 115-140.

GÓNZALEZ DE TENA, Francisco, 2014, Nos Encargamos de Todo: Robo y Tráfico de Niños en España. Madrid, Clave Intelectual.

GORDILlO, Gastón, 2006, "Fetichismos de la ciudadanía", en Gastón Gordillo, El Gran Chaco: Antropologías e Historias. Buenos Aires, Prometeo, 169-193.

HOWELL, Signe, 2004, “¿Quién soy, entonces? Perspectivas de los adoptados transnacionales sobre identidad y etnia”, en Diana Marre y Joan Bestard (comps.), La Adopción y el Acogimiento: Presente y Perspectivas. Barcelona, Universitat de Barcelona, 197-221. 
LALLEMAND, Suzanne, 1993, La circulation des enfants en société traditionnelle: prêt, don, échange. Paris, L'Harmattan.

MARRE, Diana, 2004, "La adopción internacional y las asociaciones de familias adoptantes: un ejemplo de sociedad civil virtual global”, Scripta Nova, 170 (4), disponible en < http://www.ub.edu/geocrit/sn/sn-170-4.htm > (última consulta en enero 2016).

MARRE, Diana, 2014, "Displaced children and stolen babies: state of exception, fear and public secrets in contemporany Spain”, ponencia presentada en American Anthropological Association Annual Meeting, Washington, DC.

MARTÍNEZ, María Josefina, 2004, "Paternidades contenciosas: un estudio sobre filiaciones, leyes y burocracias", en Sofía Tiscornia (comp.), Burocracias y Violencia: Estudios de Antropología Jurídica. Buenos Aires, Antropofagia, 403-432.

MARTÍNEZ, María Josefina, 2010, "La producción social de la filiación y la construcción de una paternidad”, en Carla Villalta (comp.), Infancia, Justicia y Derechos Humanos. Buenos Aires, Universidad Nacional de Quilmes, 285-316.

MATHIEU, Nicole Claude, 1977, "Paternité biologique, maternité sociale”, en Andrée Michel (comp.), Femmes, sexisme et sociétés. Paris, Presses Universitaires de France, 39-48.

MODELL, Judith, 1994, Kinship with Strangers: Adoption and Investigation of Kinship American Culture. Berkeley, University of California Press.

MOLINER, María, 2007, Diccionario de Uso del Español. Madrid, Gredos (3. a edición).

NAVARO-YASHIN, Yael, 2007, "Makebelieve papers, legal forms and the counterfeit: affective interactions between documents and people in Britain and Cyprus", Anthropological Theory, 7: 79-98.

PEIRANO, Mariza, 2006, A Teoria Vivida e Outros Ensaios de Antropologia. Rio de Janeiro, Jorge Zahar Editor.

PEIRANO, Mariza, 2009, "O paradoxo dos documentos da identidade: relato de uma experiência nos Estados Unidos”, Horizontes Antropológicos, 32: 53-80.

REGUEIRO, Sabina, 2010, Apropiación de Niños durante la Última Dictadura Militar Argentina: Tramas Burocrático-Administrativas y Estrategias Jurídico-Políticas en la Construcción de Parentescos. Buenos Aires, Facultad de Filosofía y Letras de la Universidad de Buenos Aires, tesis doctoral en Ciencias Antropológicas.

REIS, Elisa Pereira, 1998, “Opressão burocrática: o ponto de vista do cidadão”, en Elisa Pereira Reis, Processos e Escolhas. Rio de Janeiro, Contra Capa Livraria, 239-269.

SCHNEIDER, David, 1984, A Critique of the Study of Kinship. Ann Arbor, University of Michigan Press.

SCOTT, James, 1998, Seeing Like a State: How Certain Schemes to Improve Human Condition Have Failed. New Haven, Yale University Press.

SEGALEN, Martine, 1992, Antropología Histórica de la Familia. Madrid, Taurus Universitaria. STRATHERN, Marilyn, 1992, After Nature: English Kinship in the Late Twentieth Century. Cambridge, Cambridge University Press.

THÉRY, Irene, 2009, "El anonimato en las donaciones de engendramiento: filiación e identidad narrativa infantil en tiempos de descasamiento", Revista de Antropología Social, 18: 21-42.

THOMAS, Yan, 1999, El Artificio de las Instituciones: Estudios de Derecho Romano. Buenos Aires, Eudeba.

VAN GENNEP, Arnold, 1986 [1909], Los Ritos de Paso. Madrid, Taurus. 
VIANNA, Adriana, 2010, "Derechos, moralidades y desigualdades: consideraciones acerca de procesos de guarda de niños", en Carla Villalta (comp.), Infancia, Justicia y Derechos Humanos. Buenos Aires, Universidad Nacional de Quilmes, 21-72.

VILlAlTA, Carla, 2006, Entregas y Secuestros: La Apropiación de "Menores" por Parte del Estado. Buenos Aires, Facultad de Filosofía y Letras de la Universidad de Buenos Aires, tesis doctoral en Ciencias Antropológicas.

YNGVESSON, Barbara, 2007, "Parentesco reconfigurado no espaço da adoção", Cadernos Pagú, 29: $111-138$.

ZONABEND, Francoise, 1986, "De la familia: una visión etnológica del parentesco y la familia”, en A. Burguiere et al. (dir.), Historia de la Familia. Madrid, Alianza Editorial, 17-79. 